$616.995 .132 .7: 612392.45$

放射性鉄に上る鈎虫症の鉄代謝に関する研究

\author{
第 1 編 \\ 鉤虫犬の鉄代謝飞ついて \\ （本論文の要旨は第44会日本消化機病学会総会において発表した） \\ 岡山大学医学部平木内科教室（主任 : 平木 潔教授) \\ 副手上塚香
}

[昭和 34 年 2 月 7 日受稿〕

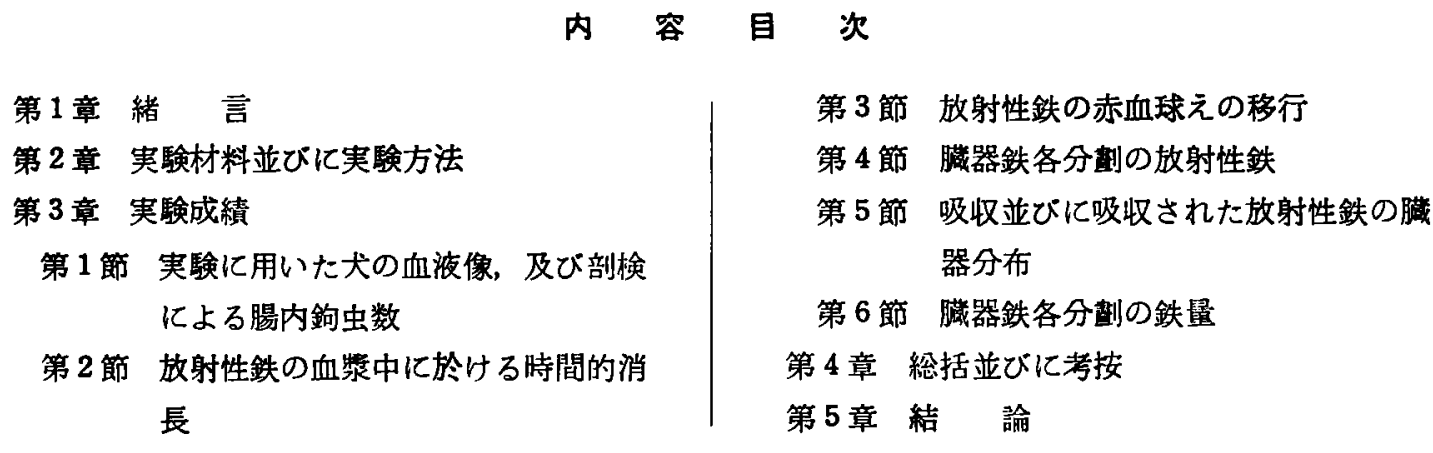

第 1 章 緒言

鉤虫症䨘血の成因に関しては古くから多くの研究 がなされているが，諸家の説は必ずしも一致してい ないそこの主なるのを大別すると消化器障害説，中 毒説，及び出血説，或は之等の綜合説である.

（1）消化器障害説は钧虫寄生に上る慢性消化器障 害，即ち消化，吸収障害によつて貧血が起るとする もので，大礎10)は人体に於ける鉤虫感热実験で感 染 3〜 4 週後頃加慢性消化器障害の起る事を認め, 太賓血の成因として出血，毒素作用と並んで何れも 甲乙なく平等の位置に於て挙ぐへきであるとし，岩 田5）は栄養失調性貧血之比较検討し，消化器障害特 に蛋白代謝異常を重視している，然るに松浦56)，真 島53)等は犬について実験し，僅か $3 \sim 4$ 週の間に 高度の貧血を来す事より, 消化器障害を貧血の主因 となし得ないとし，瀨戸27）は剖㭘上の相違から栄 食失調性貫血之区別し，福島・千田46）は本貣侐が 低色菜性であるに反し，栄養失調性貧血は正色素性 乃至高色菜性であるから，同一視する事は出来ない としている.

（2）中毒説は銁虫寄生により或種の毒が生成さ

れ，溶血的に作用して頜血を来すとするものと，造 血搭器に作用して貫血を起すと云う二者に大別され る.

（1）溶血説について見るに，鉤虫虫体内の溶血性 物質の検索についてはPreti123), 稻田3), Whipple130), 細根51)等の業辕があり，殊に細根は鉤虫乳剂を犬 に注射すれば賓血が起る。之は虫体为の溶血性毒䒺 によるあのとし，てれをアンキロリヂンと名付けて いる. 真島53）も鉤虫症負血犬の脿器鉄沈着を溶血 の為であるとしている，然し高橋・阿南31）は試験 管内実験で鉤虫乳剂に溶血作用なしとし，岡11），中 尾37)は氺中ウロビリンが略正常值を示すととより， 植村8)，山崎68)，有地2)，中尾37) 等は血清ビルビ ン量に著変なき点より，鈎虫症に於て著明な溶血現 象が起つているとは考えられないとしている。

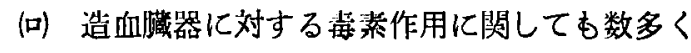
の研究が見られう，上野6) は制虫虫体のアルコール エキスを注射した县物の骨粗值に著しい造血障害像を 認め，宮川等63) は実験的鉤虫犬に脾腫を来し，骨 噵特に赤血球系に再生機能の障害がある事を見，村 田67) は鉤虫犬の血液を家兔に注射して造血組織に 著明な機能减退像を認め, 何れむ骨餚の中毒性障害 
を重視した，高橋・阿南31）は家兔に鈎虫乳剂を注射 すると貧血を起すが，ての賓血は脾の存在に於て発 現するとした，又 Fieschi87)，教室上原7) は本症患 者の剖検により骨䯣の再生不能像を認めているが, 瀬戸27）は赤血球再生機能不全は認めないとしてい る. 骨髄穿刺像に於ては宮崎等64)は Hyperregeneratorisches Mark の像を呈し，梪血びに骨檤 機能穴進を示すと云い，中尾36) 細胞数增加し赤 芽球屯多い事を認めているが，中島 ${ }^{38}$ ）は成就障害 による增生であり，中毒性であると述へている.

以上実験的研究或は臨床的検索に於て何等加の毒 秦の作用が本貫血発生に関与していることが考えら れ，乙の毒素について更に追求したあのに小森19， 浅越1)，松本57），江口・三好9）等があるが，特に北 山16）前教授はその広汎な実験 から鉤虫虫体の毒素 はアルコール不溶のものと可溶性のものとのニつよ りなり，前者は剔脾鬼に貧血を起さず，後者はこれ に反して剔脾兔に貝血を起す。而して後者は宿主の 血泎中に吸収されても，そのものは直ちに賓血を起 さず，健康な旰を通過して更に新しい物質となり， 之が骨䯣に作用して始めて貧血を起す。この物質は 中性脂肪であつて, 患者尿, 髄液中にあ移行してい る. 即与鉤虫自体は人体の腸管に寄生し，一つは局 所で失血性貫血を起すと同時に，他面何等かの機構 によつて脂肪様物質を分泌し，之が人体に吸収され， 更に他の中性脂肪に変つて, 狭義の中毒性頜血を起 すあのと結論せざるを得ないと述へておられる.

（3）出血説についてあ中毒祱之並んで多くの研究 がある. Leichtenstern116) は鉤虫症患者の剖検に於 て腸出血を認め，松浦55）は仔犬の鉤虫性貧血の血 液像並びに肉眼的血便より出血を强調し，Foster \&

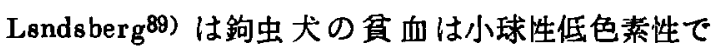
反夏渲血した犬のそれと一致し，共に鉄椷がよく奏 効する等の点より，本頜血は純轨な出血性蚠血であ ると述へている. Wells(29)，西42)，梁45) は犬鉤虫 の吸血状況を観察し，1隻による1 日の血液損失量 を計算し，失血をむつて本䨘血の主因としている。 又臨床的にも本症に腸出血のある事は多くの人の認 める処であつて, 篦便潜血反応検查で佐野22)は90.8 \%。，中尾37)は87.8\%，教室柴田23)は85.7\%陽性 である事走しており，腸出血が本症貝血の重要な る一因子である事を疑うるのはいない．

而して鈎虫症負血は小球性，低色䋕性て，血清跌 は減少し，臨不的にも鉄剂の投与により或程度䨘血 の改善を認め，鉄欠乏性寊血である事は現在周知の
事であつて，本貫血の成因究明に際して鉄代謝面か らの研究が如何に重要であるかは論を俟たな い. 生体の鉄代謝に関する研究は，Heilmyer u. Ploetner 109) が血清鉄の定量法に新機軸を開き，又 Hahn90)等によつて放射性鉄を追跡子とする実䀫方 法が導入されて以来急速に進展し, 数多くの新知見 が得られた. 鉤虫症に於ても近年鉄代謝の面加らの

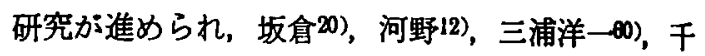
田・石上 ${ }^{30)}$ ，中尾34），三浦寛的，教室米谷 ${ }^{52)}$ 等に より血清鉄の減少が報告されている，福島・千田46) は本症患者に対する還元鉄投与試験及び駆虫実検に 於ける血清鉄の変動加ら，本症貝血の発生機序に関 しては鉄の吸収及び動員の障害に加うるに出血によ る鉄欠之がその主因をなしているとし，教室米谷㗏) 屯鉤虫感染及び駆虫実験に於ける血清鉄の変動加ら 鈞虫症に於りる鉄の動員障害を考え，更漄負血性 物質を含む鉤虫症患者血清を注射すると，網内系溸 能の健全な動物に限り貫血並びに血清鉄の减少を来 すことを認め, 同時に該動物の䑏器鉄の増加を染色 法と比較定量法とを用いて証明して，鈎虫症頜血は 純杵な鉄欠之性實血之云うよりは鈎虫寄生によつて 個体血清中に産生される毒素により鉄か網内系に抑 留される. 即ち鉄眝䑏器よりの鉄の動員の障害の為 に，造血に利用される鉄の欠之を来す事が主因であ ると強調している，教室中塚400 は更に一歩進んで 実験的鈎虫犬並びに鈎虫应患者血清注射家鬼の滕器 非へミン鉄を分嚑定量し，その增加を認めて，本症 に於ける鉄の動員障害を確認し，鈎虫症患者に於け ろ還元鉄吸収試験で吸収の障害されている例の方が 多い事を示している，岩城4す犬への鈎蚂蝛架 実験で血清鉄の变動に関して米谷62) と略同様の結 果を得，放射性鉄を利用して鉤虫感染に上る失血量 を計算し，之に基いて犬の渞血実殹を行つたが，鈎 虫症に見られる如き著明な賽血並びに低血清铁症は 認められない事及び鉄の吸収，血色美合成への利用 等の研究加ら，本䨘血の鉄欠之は腸管内への出血儿

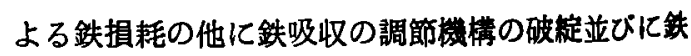
眝蔵庫よりの動員の障害によるものと考えてい る.

以上の如く鉤虫症䨘血の成因究明の為に種々㮥索

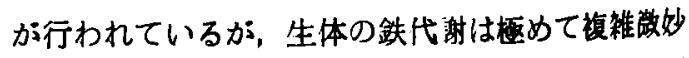
で，吸収，眝蔵，動員利用，並びに之等の間を結ら゙ 血清鉄等の相互関連のもとに営まれているのであつ て，鈎蛼疮於てあ之等がその一面のみからてなく， 綜合的に把握されるのでなりれ傎の姿をうかがう 
ととは出来ない，著者は上記教室の業績に引続いて 钩虫症貧血の成因を鉄代謝の面から棕合的且動的に 把暒しようとして，次の如き実験を行つた．即ち鈎 虫犬に放射性鉄を経口投与して，その吸収，利用及 び膡器分布等を見, 同時に脿器鉄量を測定して, 鉤 虫症に於ける鉄代謝を検討し，更に鉤虫症血清及び 钩虫乳剂を注射した家鬼に放射性鉄を経口投与して 同様に実験し，鈎虫毒素の鉄代謝に及に゙す影響につ いて検索した．本編では先づ鈎虫犬の鉄代謝につい て述へろ.

\section{第 2 章 実硂材料並び実験方法}

\section{実験動物}

生後 1 ケ年内外の体重 $5 \sim 10 \mathrm{~kg}$ の雄性犬を使用 した． 2 週間以上一定条件のもとに飼育し，その間 亿 3 回以上検便して腸内寄生虫なき事を確め，血液 像供常を認めないもの 6 例の中 3 例を健康対照犬 とし，3例任鈎虫仔虫を経口感染させ，感染後30日 を経て貫血が著明になつた時期に実験に用いた（実 験的鈎虫犬). 又便任鈎虫卵多数を認め, 他の虫卵 陰性で貝血の認められるもの 6 例を選び，3例を自 然感染鈞虫犬とし，3 例を駆虫して30日間放置し， 夫々実験に供した，尚この際用いた鉤虫感染及び駆 虫方法は次の如くである. 即ち鉤虫卵を含む犬の便 を $28^{\circ} \mathrm{C}$ で瓦培養し，仔虫の浮游液を軽く遠心，沈 渣に少量の常水を加えてよく混和し，その0.1 ccを 载物硝子に移し，被覆硝子で覆い，顕微鏡下に仔虫 数を計算し, $0.1 \mathrm{cc}$ 中の仔虫数の平均值を求め, 3000隻に必要な量を少量の牛釈に混じて提食せしめ た、駆虫には連続 3 日間テトレン球及び硫苦を用い， 其後の萁便検査により完全駆虫を確めた。

\section{実験方法}

前述せる健康対照犬，実験的鉤虫犬，自然感染鉤 虫犬及び駆虫犬に放射性鉄を経口投与し，経時的に 血整及び赤血球中の放射能を測定し，48時間後に生 体灌流して，米山・紺野72) 氏法に従い諸腈器非へ ミン鉃を分䚯し，その放射能及び鉄量を測定した。

1）放射性鉄の調整法及び投与量：体重毎 $\mathrm{kg}$ $60 \times 10^{4}$ c. p. m. (Count per minute) k相当する故 射性鉄液（ $\left.\mathrm{Fe}^{59} \mathrm{Cl}_{3}\right)$ を遠心沈凯管にとり，鉄量と して毎 $\mathrm{kg} 0.25 \mathrm{mg}$ となる様汇非活性の鉄液（Fe Cls）を加え，之に苛性ンーダ溶液を加えて水酸化 第二铁として遼心沈测し，上清を除き，鉄量の約 5 倍のアスコルビン酸を加えてよく混し，少量の水を 足して掣色透明の溶液となる迄よく振通し，2 価の
形として之を直に経口投与した。

2）䓡器非へミン鉄の分舦测定法：程口投与後 48時間目に米山・紺野 72) 氏法に従い，肝，脾，骨 随, 十二指腸上部の非へミン鉄を分剽測定した。即ち Bogniard76) 等の方法に準じ生理的食塩水を用いて 生体灌流を行つた後直ちに被検臟器 $2 \mathrm{~g}$ をとる(て の際十二指腸上部は表面に付着した放射性鉄を除く 為, 生理的食盐水で数回洗涤した). 之に生理的食 塩水を加えて細挽し, $80^{\circ} \mathrm{C} 10$ 分間加熱後遠心沈澱 して沈渣をPI とし，ての上清に $P_{I}$ を生理的食塩 水で2回洗滌したものを加えて SI とする．SI を更 に $100^{\circ} \mathrm{C} 30$ 分間加熱し, 遠心沈溅して沈楂をPI と する. 上清 $\mathrm{S}_{\mathrm{II}}$ に酶酸楥衝液を加えて $\mathrm{pH}$ 4.0とし， 之を $100^{\circ} \mathrm{C} 30$ 分間加熱後遠心沈溅し沈渣をP III, 上清を $\mathrm{SIII}$ とする。各沈楂 $\mathrm{P}_{\mathrm{I}}^{\prime}, \mathrm{P}_{\mathrm{II}}, \mathrm{P}_{\mathrm{III}}$, に10\% 三塩化酢酸と 496 ピロ燐酸ソーダの等最混合湤を加 えて遠心沈激し，更に沈楂に上記混合液を加え 2 回 洗條した上清を集めた．各分劃を全量 $25 \mathrm{cc}$ として よく混和し，その半量 $12.5 \mathrm{cc}$ をとり,フェノール フタレインを指示薬としてアンモニアで中和した後 酢酸楥衝液を加え $\mathrm{pH} 4.7$ とする. チオグリコール 酸 1 滴，0.19オルトフェナントロリン $1 \mathrm{cc}$ を加え て発色せしめ, 全量 $25 \mathrm{cc}$ に稀釈して日立兆電比色 計によつて比色定量した。

3）放射能の測定法

s）試料の採取方法：放射能を測定した試料は 血䈋, 赤血球及び肝, 脾, 胃㖪, 十二指腸上部の非 ヘミン鉄各分剽である．放射性鉄経口投与後 $1,2,4$, $6,12,24$ ，48時間目に犬の前脚静脈を穿刺採血し，二

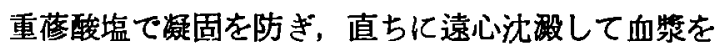
分離して，その $1 \mathrm{cc}$ をとり，残りの血球層を生理 的食塩水で数回洗涤し，最後に 1 分閒 3000 迴転で10 分間遠心沈激し，上清を出来るだけ除去した後血球 を $1 \mathrm{cc}$ 採取する.葴器非へミン鉄各分剽の放射能 の测定には前述鉄量測定の際の残り半量 $12.5 \mathrm{cc}$ を 用いた。

b）測定方法：上記試料を一定の試料皿にとり， 神戸工業製シンチレイション計数管 PS-1 型及び 1000進法高速計数装置を用いて，同一条件の下で, 同時に10分間測定した。

実験数值の算出法

赤血球の総量は Hahn102)，Balfour ${ }^{75)}$ 等に従つ て次式により, 
赤血球総淂＝体重 $(\mathrm{kg}) \times 80 \times \mathrm{Ht}$ (静脈血) $\times 0.75$

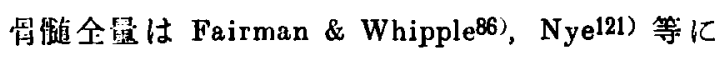
準じて体重（g）の2\%とし，朋，脾は重量を計つ て，赤血球，留骮道，肝，脾の放射性鉄の投与量に対 する百分率を求めた。

\section{第3 章 実験成 精}

第 1 節 実験に用いた犬の血液像，及び剖 検による晹内鉤虫数（第 1 表）

実験的鈎虫犬は前述の如く大冒の鈎虫仔虫（3000 隻）を一時に経口感染させたもので，何妃も著明な
血便を認めた。但し著明な血便が続いた期間が夫々 異り, No. 1 は感染後10日目加ら約10日間, No.3 3 は 感染後 5 日目から約 2 週間, No. 4 は感染後 4 日目 から実験に供する迄27日間であつた，そして䖝液像 では何れす相当著明な貧血を示しているが，ての䨘 血の程度は著明な血便が長く続いたもの程強くなつ ている，自然感染鉤虫犬は，人工的に鈎虫仔虫を感 染させないのに，便に多数の鈎虫卵を認めたあのて あつて, この場合は肉眼的に羿められる程著明な血 便は見られず，血液像でも実験的鈎虫犬程强度の賈 血を認めなかつた。駆虫犬は自然感浩鈎虫犬を駆虫

第 1 表 血液像及び鉤出数

\begin{tabular}{|c|c|c|c|c|c|c|c|c|}
\hline & 犬番号 & $\begin{array}{c}\text { 体 重 } \\
(\mathrm{kg})\end{array}$ & 経 過 日数 & $\begin{array}{c}\text { 血色素量 } \\
\text { (\%) }\end{array}$ & 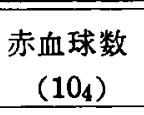 & $\begin{array}{c}\text { 網状赤血球数 } \\
(\% 0)\end{array}$ & 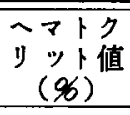 & 腸内鈎虫数 \\
\hline 健 & No. 2 & 6.3 & & 90 & 540 & 6 & 45 & 0 \\
\hline 康 & No. 7 & 8.3 & & 90 & 636 & 9 & 47 & 0 \\
\hline 犬 & No. 12 & 7.5 & & 94 & 618 & 7 & 48 & 0 \\
\hline \multirow{6}{*}{$\begin{array}{l}\text { 螓 } \\
\text { 㿟 } \\
\text { 銁 } \\
\text { 虫 }\end{array}$} & No. 1 & & 前 & 92 & 552 & 7 & & \\
\hline & 200. & 9.0 & 感染後30日 & 55 & 465 & 21 & 32 & 44 \\
\hline & No. 3 & & 前 & 95 & 565 & 11 & & \\
\hline & & 6.0 & 感染後30日 & 45 & 332 & 24 & 23 & 397 \\
\hline & No 4 & & 前 & 90 & 594 & 9 & & \\
\hline & & 6.1 & 感染後30日 & 22 & 215 & 26 & 10 & 375 \\
\hline \multirow{3}{*}{$\begin{array}{l}\text { 自銁 } \\
\text { 然感虫 } \\
\text { 架犬 }\end{array}$} & No. 6 & 6.0 & & 68 & 459 & 4 & 36 & 242 \\
\hline & No. 9 & 7.5 & & 70 & 492 & 3 & 34 & 117 \\
\hline & No. 10 & 7.0 & & 71 & 435 & 10 & 35 & 46 \\
\hline \multirow[b]{2}{*}{ 駆 } & No 5 & & 前 & 65 & 439 & 3 & & \\
\hline & & 5.0 & 駆虫後30日 & 74 & 521 & 11 & 40 & 0 \\
\hline \multirow{2}{*}{ 虫 } & No. 8 & & 前 & 74 & 465 & 5 & & \\
\hline & & 7.5 & 駆虫後30日 & 80 & 525 & 21 & 38 & 0 \\
\hline \multirow{2}{*}{ 犬 } & No 11 & & 前 & 68 & 471 & 7 & & \\
\hline & & 8.5 & 駆虫後30日 & 77 & 533 & 15 & 41 & 0 \\
\hline
\end{tabular}

したもので，駆虫前の貫血の程度は自然感热鉤虫犬 のそれと略同じであり，駆虫後30日目には貧血が可 成恢復している，腸内鉤虫数は实験的鉤虫犬の方が 自然感染鈎虫犬より多いが, 前者の鈎虫は後者の鉤 虫に比して可成小さく，幼若な観が強かつた。

第 2 節 放射性鉄の血䏺中に於ける時間的 消長（第 2 表，第 1 図）

最高值を示すのは各例共 1 又は 2 時間目で，実験 的鉤虫犬の 1 例のみが 4 時間目となつている. 最高 值を相互に比校すると，最も著明なのは実験的鉤虫
犬で, 健康犬の $7 \sim 8$ 倍に達する. 但し実験的钧虫 犬の 1 例（No.4）は例外的任低値て，健康犬の $1 / 2$ 〜 1/3 の值を示した. 然しての例も後述赤血球中の 放射能は他の 2 例以上儿高值で，最高の值を示して いる点興味深い，次に高值を示しているのは駅蚛 で, 健康犬の $2 \sim 5$ 倍である. 自然感染制蚛の 2 例は極めて低值で，健康犬の $1 / 4$ 以下であるが， 極わて高值で，実験的鈎虫犬と大差ない值を示した

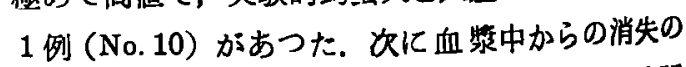
様子を見ると，何れも急速汇減少して，6１2時間 
第 2 表 経口投与世る放的性鉄の血呇中に於け る時間的消沶

count $/ 10 \mathrm{~min}$. $/ \mathrm{cc}$.

\begin{tabular}{|c|c|c|c|c|c|c|c|c|}
\hline & 待 & 1 & 2 & 4 & 6 & 12 & 24 & 48 \\
\hline 健 & No. 2 & 86 & 262 & 2940 & 666 & 182 & 28 & 32 \\
\hline 康 & No. 7 & 072 & 6000 & 1706 & 774 & 201 & 172 & 112 \\
\hline 犬 & No. 12 & 944 & 4214 & 2615 & 413 & 115 & 65 & 92 \\
\hline & No. 1 & 30262 & 45632 & $11808^{\prime}$ & 1574 & 368 & 188 & 106 \\
\hline & No. 3 & 38926 & 6782 & 2308 & 410 & 358 & 118 & 572 \\
\hline 犬 & No. 4 & 20 & 02 & 1910 & 1098 & 415 & 326 & 136 \\
\hline & No. & 528 & 712 & 390 & 266 & 96 & 30 & 68 \\
\hline 虫 & No. 9 & 1102 & 848 & 250 & 104 & 59 & 68 & 14 \\
\hline & No. 10 & 37836 & 16944 & 9326 & 1568 & 211 & 1061 & 70 \\
\hline 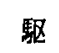 & No. 5 & 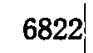 & 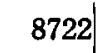 & 4010 & & 242 & 122 & 216 \\
\hline 生 & No. 8 & 20032 & 17892 & 3186 & 900 & 321 & 140 & 216 \\
\hline 犬 & No. 11 & 15341 & 10345 & 260 & 1325 & 248 & 95 & 146 \\
\hline
\end{tabular}

\section{第 1 図 経口投与世る放射性鉄の血焚中几於け} る時間的消長（代表例）

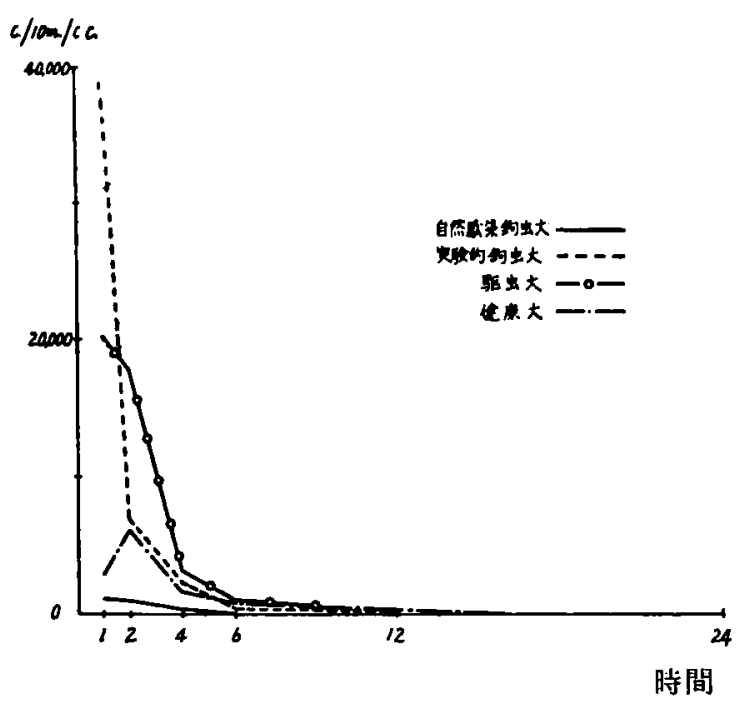

で㱠ど消失しているが，最初に高值を示したもの程 急蹢な曲線を示し，自然感染鉤虫犬ては減少が比較 的緩慢で，平坦な曲線を示している様に思われる。

\section{第3 節 放射性鉄の赤血球への移行（第 3 表, 第 2 図)}

実験的鉤虫犬では 4 時間目に既に可成な高值を示 し，以後急激に增加して，48壯間目には健承犬の10 〜30倍となる. 之に次いで高值を示すのは駆虫犬で, 4 時間目頃から赤血球中に放射性鉄が出現し，比较 的急な線をえがいて上昇し，48時間目には趾康犬の
第 3 表 経口投与せる放射性:鉄の赤血球への移行 count $/ 10 \mathrm{~min}$. $/ \mathrm{cc}$.

\begin{tabular}{|c|c|c|c|c|c|c|}
\hline & 犬番号 & 4 & 6 & 12 & 24 & 48 \\
\hline 健 & No. 2 & 132 & 176 & 1024 & 1596 & 4038 \\
\hline 康 & No. 7 & & 528 & 899 & 5334 & 6740 \\
\hline 犬 & No. 12 & 75 & 324 & 1215 & 3447 & 5924 \\
\hline 実鉊 & No. 1 & 1690 & 2368 & 4052 & & 59166 \\
\hline 験虫 & No. 3 & 7724 & 10400 & 17900 & 20290 & 1542 \\
\hline 的犬 & No. 4 & 11106 & 14500 & 56295 & 122280 & 202034 \\
\hline 自鈎 & No. 6 & 4 & 76 & 116 & 222 & 61 \\
\hline 然出 & No. 9 & 28 & 54 & 70 & 114 & 963 \\
\hline 染犬 & No. 10 & & 444 & 1865 & 5804 & 12764 \\
\hline 駆 & No. 5 & 238 & 492 & 1078 & 3326 & 17216 \\
\hline 虫 & No. 8 & 820 & 1180 & 4397 & 12432 & 31794 \\
\hline 犬 & No. 11 & 556 & 844 & 2519 & 8599 & 22191 \\
\hline
\end{tabular}

第 2 図経口投与世る放射性鉄の赤血球への移 行 (代表例)

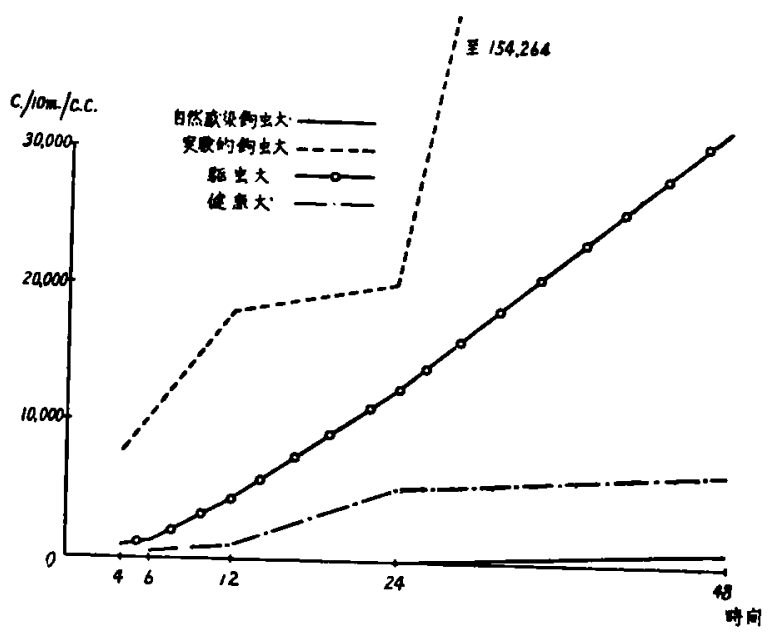

$3 \sim 5$ 倍の俻を示す, 自然感染鉤虫犬の 2 例は12時 間目位から出現しはじめるが，極めて低值で，48時 間目にも健康犬の 1/5〜1/7 である. 1 例 (No. 10) は可成な高伯で, 健䐂犬と駆虫犬の略中間の值を示 している.

\section{第 4 節 葴器鉄各分劃の放射性鉄（第 4 表, 第 3 困)}

実験的鉤虫犬は各臟器共 $P_{I}$ に於て高值を示し, 特に骨髉，十二指腸，脾に多く，PIIでは各䑏器共 他に比してむしろ低值である，自然感染鉤虫犬は健 康犬，駆虫犬に比挍して肝の PI， PII ではやや低值， 骨䯣, 脾の $\mathrm{P}_{\mathrm{I}}, \mathrm{P}_{\mathrm{II}}$ では大差を認めない, 駆虫犬 は各葴器各分港共健康犬と大差がない，十二指腸に 


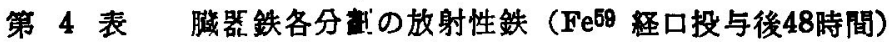
count $/ 10 \mathrm{~min} . / \mathrm{g}$.

\begin{tabular}{|c|c|c|c|c|c|c|c|c|c|c|c|c|c|c|c|c|c|c|c|c|c|}
\hline & & & 所 & & & & & 脾 & & & & & 骨 & & 髄 & & & $+=$ & 二 指 & & \\
\hline 10 & \begin{tabular}{ll|}
$\mathbf{P}$ & $\mathbf{P}$
\end{tabular} & P II & P III $\mathrm{s}$ & S III & 計 & P I & P II & P II & s III & 言 & $\mathbf{P}$ & & II $P$ & P III & s III & 計 & P I & $\mid \begin{array}{l}\mathrm{P} \\
\text { II }\end{array}$ & $\mathbf{P}$ III & S III & 計 \\
\hline
\end{tabular}

\begin{tabular}{l|l|l|l|l|l|l|l|l|l|l|l|l|l|l|l|l|l|l|l|l|}
\hline 保建 & No. 2 & 690 & 578 & 126 & 78 & 1472 & 616 & 504 & 164 & 96 & 1380 & 1244 & 1190 & 400 & 1696 & 4530 & 1280 & 60 & 450 & $402 / 2192$
\end{tabular}

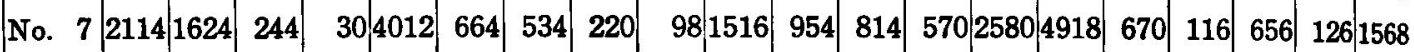

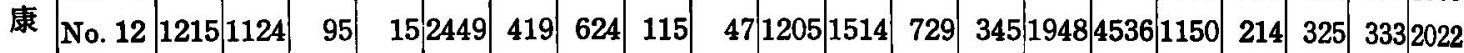

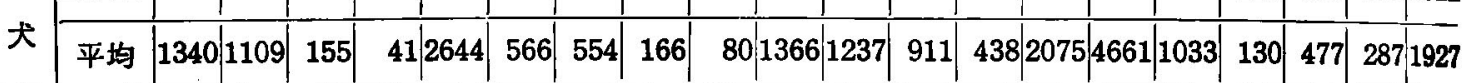

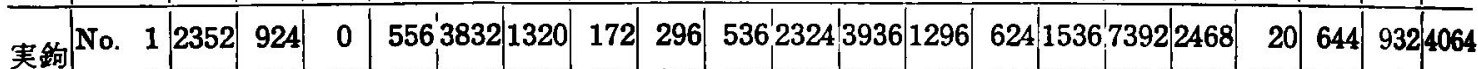
\begin{tabular}{ll|l|l|l|l|l|l|l|l|l|l|l|l|l|l|l|l|l|l|} 
No. 3 & 2220 & 584 & 150 & 6223576 & 3286 & 274 & 812 & 628 & 5000 & 6386 & 524 & 640 & 10648514 & 3502 & 714 & 1140 & 432 & 5788
\end{tabular}

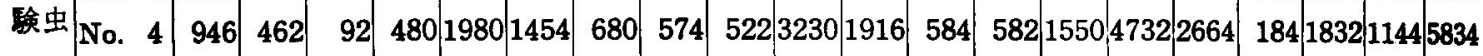

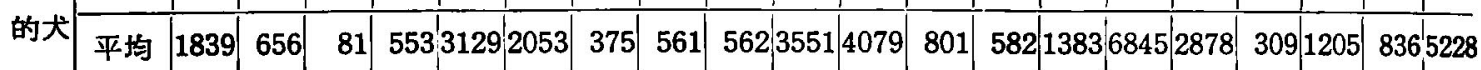

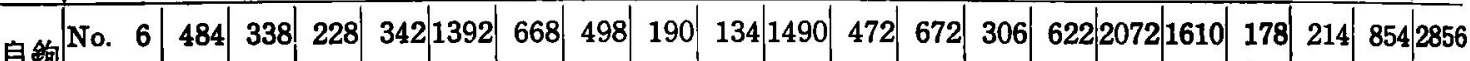

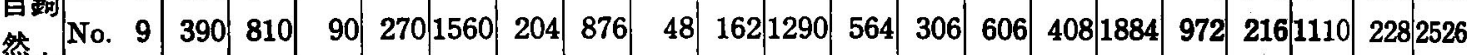

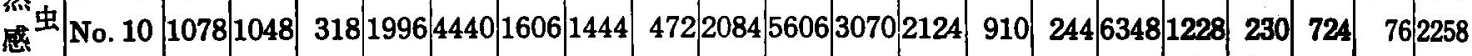

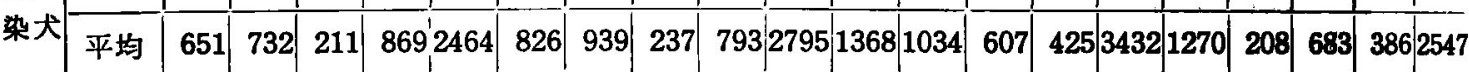
\begin{tabular}{l|l|l|l|l|l|l|l|l|l|l|l|l|l|l|l|l|l|l|l|l|}
\hline No. 5 & 768 & 982 & 364 & 176 & 2290 & 748 & 530 & 492 & 190 & 1960 & 490 & 566 & 118 & 584 & 1758 & 812 & $:$ & 8 & 778 & 560 \\
\hline
\end{tabular}

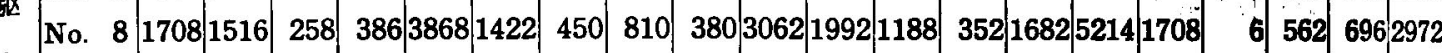

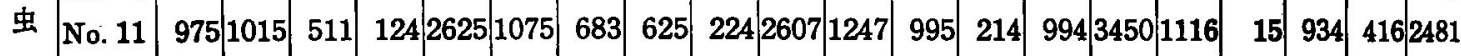

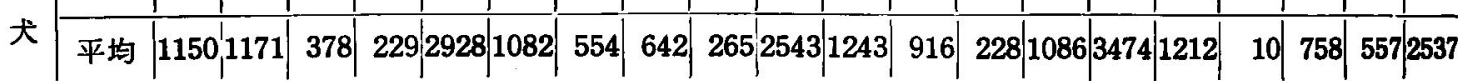

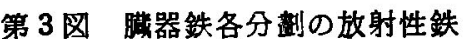

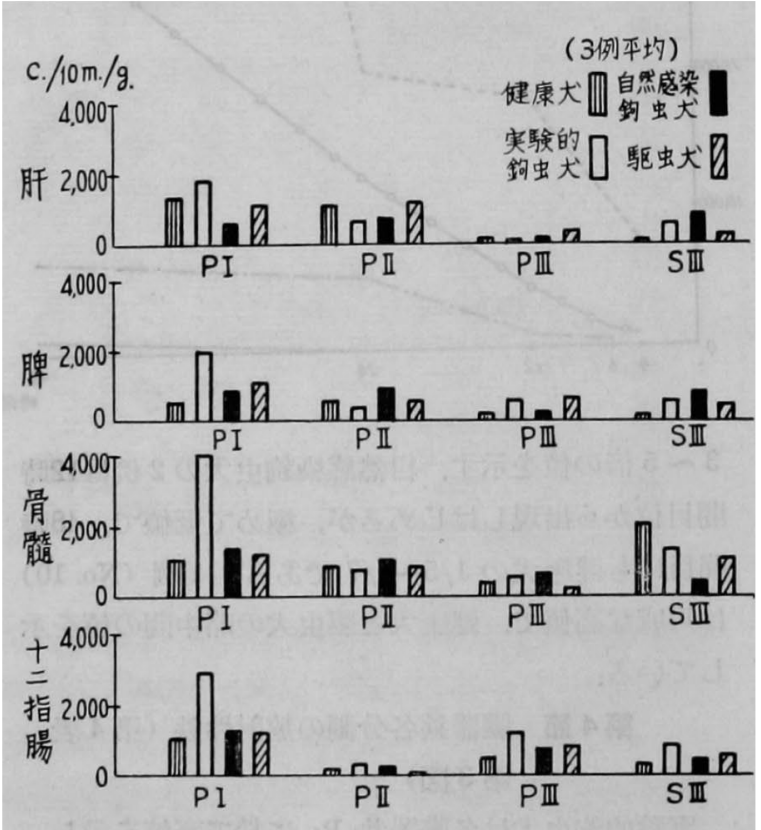

於ては実験的鈎虫犬が $P_{I}$ に特に多く，他分割であ やや高值を示す他，特別の傾向を認めない，尚 PIII，SuI は一般に比較的低値で，一定の傾向を認 めない
第 5 節 吸収並びに吸収された放射性鉄の 䑏器分布

経口投与後48時間目の赤血球，肝，脾，骨䯣の全 放射性鉄の投与量に対する百分率を第 5 表に示す。 赤血球，肝，脾，骨䯣の放射性鉄の投与量に対する 百分率の和は吸収率に近い值を示すと考えられ，以 後吸収率と云う語はこの和を意味する，吸收率を相 互に比較する之第 4 図の如く，健康犬は $5 \sim 6 \%$ ， 実験的鈎虫犬は压倒的に多く23 40\%て健康犬の約 $5 \sim 7$ 倍, 駆虫犬が之に次ぎ, $8 \sim 15 \%$ て健康犬の 1.5 3 倍, 自然感染鉤虫犬の中 2 例は䄪 $2 \%$ て めて低值で, 健康犬の約 $1 / 3$, 他の 1 例 (No. 10) は8.4\%て趾康犬よりやや多く，駆虫犬に近く，駆 虫犬 No. 5 と殆ど同じである. 更に吸収された放射

第 4 图吸收率（Fe日9 経口投与後48時間）。

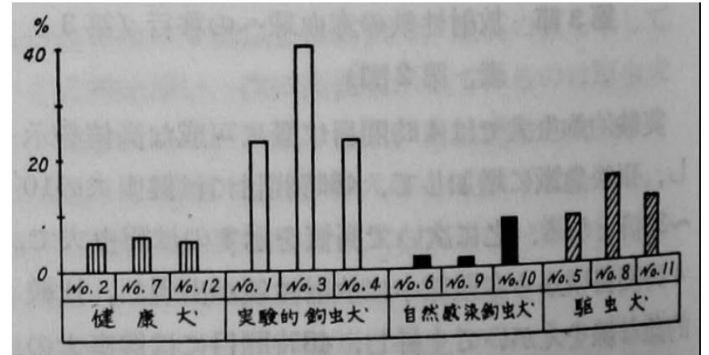


第 5 表 赤血球及び朋，脾，骨䯣の放射性鉄の投与量飞対する百分率（\%)

( $\mathrm{Fe}^{59}$ 経口投与後48㭙間)

\begin{tabular}{|c|c|c|c|c|c|c|c|c|c|c|c|c|c|c|}
\hline \multirow{2}{*}{\multicolumn{3}{|c|}{ 犬番号 }} & \multicolumn{3}{|c|}{ 硉 康 犬 } & \multicolumn{3}{|c|}{ 実験的鵨虫犬 } & \multicolumn{3}{|c|}{ 自然感染銁虫犬 } & \multicolumn{3}{|c|}{ 駆 虫 犬 } \\
\hline & & & No. 2 & No. 7 & No. 12 & No. 1 & No. 3 & No. 4 & No. 6 & No. 9 & No. 10 & No. 5 & No. 8 & No. 11 \\
\hline \multirow[t]{3}{*}{ 赤 } & 血 & 球 & 3.03 & 2.97 & 2.84 & 18.93 & 35.48 & 20.20 & 0.22 & 0.33 & 4.47 & 6.89 & 12.08 & 9.10 \\
\hline & 肝 & & 0.63 & 1.49 & 0.85 & 1.68 & 1.88 & 1.35 & 1.03 & 0.73 & 1.74 & 1.08 & 1.53 & 0.88 \\
\hline & 脾 & & 0.04 & 0.05 & 0.03 & 0.09 & 0.29 & 0.16 & 0.05 & 0.06 & 0.13 & 0.07 & 0.08 & 0.06 \\
\hline \multirow[t]{2}{*}{ 骨 } & & 䱊 & 1.51 & 1.64 & 1.51 & 2.46 & 2.84 & 1.58 & 0.69 & 0.63 & 2.11 & 0.59 & 1.74 & 1.15 \\
\hline & 計 & & 5.21 & 6.15 & 5.23 & 23.16 & 0.49 & 23.29 & 1.99 & 1.75 & 8.41 & 8.63 & 15.43 & 11.19 \\
\hline
\end{tabular}

性鉄が赤血球，肝，脾，骨髄の各々にどの様な比率

して百分率で嘉わすと，第 6 表の如くである．即ち で分布しているかを見る為に，之等の計を100\%と

実験的鈎虫犬では赤血球へ移行する率が極めて高く， 第 6 表 放射性鉄 の䑏器分布（\%)（Fe59 経口投与後48時間）

\begin{tabular}{|c|c|c|c|c|c|c|c|c|c|c|c|c|c|c|}
\hline \multirow{2}{*}{\multicolumn{3}{|c|}{ 腄器名犬番号 }} & \multicolumn{3}{|c|}{ 垏 康 犬 } & \multicolumn{3}{|c|}{ 実験的跔虫犬 } & \multicolumn{3}{|c|}{ 自然感染鈎虫犬 } & \multicolumn{2}{|c|}{ 駆 虫 } & \multirow{2}{*}{ 犬 } \\
\hline & & & No. 2 & No. 7 & No. 12 & No. 1 & No. 3 & No. 4 & No. 6 & No. 9 & No. 10 & No. 5 & No. 8 & \\
\hline \multirow[t]{3}{*}{ 赤 } & 血 & 球 & 58.2 & 48.3 & \begin{tabular}{|l|l|} 
& 54.3
\end{tabular} & 81.7 & 87.6 & 86.7 & 11.1 & 18.9 & 53.2 & 79.8 & 78.3 & \begin{tabular}{l|l|l}
3 & 81.3
\end{tabular} \\
\hline & 肝 & & 12.1 & 24.2 & 16.3 & 7.3 & 4.6 & 5.8 & 51.8 & 41.7 & 20.7 & 12.5 & 9.9 & 7.8 \\
\hline & 聘 & & 0.8 & 0.8 & 0.6 & 0.4 & 0.7 & 0.7 & 2.5 & 3.4 & 1.5 & 0.8 & 0.5 & 0.5 \\
\hline \multirow[t]{2}{*}{ 骨 } & & 能 & 29.0 & 26.7 & $\mid 28.9$ & 10.6 & 7.0 & 6.8 & 34.7 & 36.0 & 25.1 & 6.8 & 11.3 & \begin{tabular}{l|l}
3 & 10.3
\end{tabular} \\
\hline & $a_{1}$ & & & & & & & & 0.0 & 0.0 & & & 0.0 & | \\
\hline
\end{tabular}

他䑏器に低率であり，特て肝，骨稙で著朋に低い。 駆虫犬は実铪的鉤虫犬に近い傾向を示すが，之に比 較すると赤血球にやや低率で，肝にやや多い，健隶 犬では約55\%が赤血球に移行している．自然感染合 虫犬は極めて特異な㑯向を示す。即ち No. 6, No. 9 では赫球へ移行する率は極めて低く，健隶犬の $1 / 3 \sim 1 / 5$, 駆虫犬の $1 / 4 \sim 1 / 7$, 実㩆的唋虫犬の 1/5 1/8 の割合である. 之に反して，胉，脾，骨

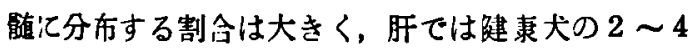
倍, 駆虫犬の約 4 倍，実跧的钧虫犬の $6 \sim 10$ 宰，脾 では趾隶犬，駆虫犬の $3 \sim 4$ 倍，奏㰸的泃虫犬の 4 $\sim 8$ 倍, 骨慖では健隶犬の約 1.3 倍, 䟓虫犬の $3 \sim$ 5 倍である.No.10は健隶犬に近い僋向を示してい るが, 熷汸於て高率で，他の 2 〜 倍の值を示して 书り，吸収率つ咯等しい聑虫犬 No. 5 と比校すると， 赤血球汇少く肝，脾，骨檤儿高率化分布し，程度の 差はあるが他の 2 例と同じ傾向を示している。

以上要約すると，実臾的筍虫犬及び駆虫犬では吸 収率が高く，吸収された鉄の大部分浾系球洺行 し，肝，脾，骨骮化分布する率極》て低い：この 傾向は前者う方が著鹏である，自然热染岣虫犬は之

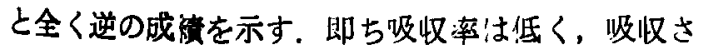

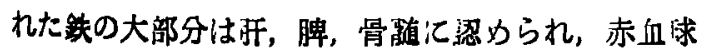

に移行する率は極めて低い。

第 6 節 歲器跌各分别の鉄量 第 7 表淿す通りて，各平均值を相互に比较する と，第 5 図つ如くである. 実検的谪虫犬では各䑏器

第 5 図膜器鉄各分剽の鉄量

(3甽平均)

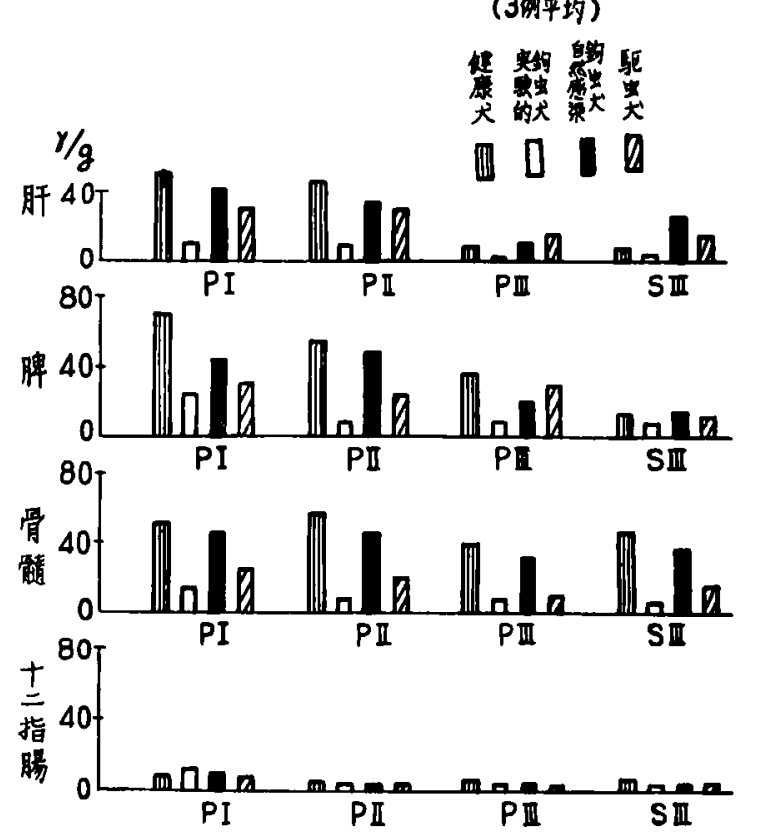


第 7 表䑏器鉄各分䢞の鉄量 $(\gamma / \mathrm{g})$

\begin{tabular}{|c|c|c|c|c|c|c|c|c|c|c|c|c|c|c|c|c|c|c|c|}
\hline & \multirow{2}{*}{$\left|\begin{array}{c}\multicolumn{1}{c}{\text { 朖器 }} \\
\text { 犬 } \\
\text { 番号 }\end{array}\right|$} & \multicolumn{5}{|c|}{ 肝 } & \multicolumn{5}{|c|}{ 脾 } & \multicolumn{2}{|r|}{ 骨 } & \multicolumn{2}{|c|}{ 檤 } & \multicolumn{4}{|c|}{ 十二指腸 } \\
\hline & & $\begin{array}{l}\text { 重量 } \\
(\mathrm{g})\end{array}$ & P I & P II & P III & S III & $\begin{array}{l}\text { 重量 } \\
(\mathrm{g})\end{array}$ & P I & P II & P III & $\mathbf{S}$ III & P I & P II & P III & S III & P I & $\mathbf{P} \mathbf{I I}$ & P III & S III \\
\hline \multirow{4}{*}{$\begin{array}{l}\text { 健 } \\
\text { 康 } \\
\text { 犬 }\end{array}$} & No. 2 & 162 & 34 & 24 & 4 & 7 & 11.5 & 75 & 44 & 21 & 13 & 34 & 37 & 12 & 25 & 9 & 3 & 4 & 6 \\
\hline & No. 7 & 185 & 65 & 67 & 12 & 10 & 17.0 & 63 & 65 & 51 & 12 & 67 & 75 & 67 & 68 & 9 & 4 & 10 & 7 \\
\hline & No. 12 & 157 & 55 & 51 & 6 & 11 & 12.5 & 59 & 61 & 19 & 8 & 42 & 38 & 11 & 21 & 7 & 6 & 5 & 5 \\
\hline & 平均 & & 51 & 47 & 7 & 9 & & 66 & 57 & 30 & 11 & 48 & 50 & 30 & 38 & 8 & 4 & 6 & 6 \\
\hline \multirow{4}{*}{$\begin{array}{l}\text { 実验 } \\
\text { 験虫 } \\
\text { 的犬 }\end{array}$} & No. 1 & 237 & 8 & 3 & 1 & 0 & 21.0 & 15 & 3 & 5 & 5 & 13 & 4 & 3 & 5 & 6 & 0.5 & 2 & 4 \\
\hline & No. 3 & 189 & 13 & 11 & 5 & 2 & 21.0 & 23 & 8 & 9 & 7 & 13 & 8 & 7 & 6 & 13 & 8 & 6 & 2 \\
\hline & No. 4 & 245 & 13 & 13 & 4 & 6 & 18.0 & 35 & 16 & 11 & 11 & 17 & 15 & 13 & 9 & 17 & 4 & 5 & 3 \\
\hline & 平均 & & 11 & 9 & 3 & 3 & & 24 & 9 & 8 & 8 & 14 & 9 & 8 & 7 & 12 & 4 & 4 & 3 \\
\hline \multirow{4}{*}{$\begin{array}{l}\text { 自鈎 } \\
\text { 然虫 } \\
\text { 感 } \\
\text { 染犬 }\end{array}$} & No. 6 & 195 & 31 & 31 & 13 & 29 & 10.5 & 31 & 36 & 12 & 18 & 30 & 31 & 23 & 20 & 8 & 2 & 2 & 2 \\
\hline & No. 9 & 210 & 35 & 35 & 9 & 29 & 21.0 & 32 & 36 & 27 & 16 & 29 & 37 & 35 & 33 & 7 & 3 & 6 & 5 \\
\hline & No. 10 & 165 & 61 & 26 & 12 & 18 & 10.0 & 68 & 71 & 29 & 12 & 79 & 67 & 37 & 54 & 19 & 5 & 4 & 5 \\
\hline & 平均 & & 42 & 34 & 11 & 25 & & 44 & 48 & 23 & 15 & 46 & 45 & 32 & 36 & 11 & 3 & 4 & 4 \\
\hline \multirow{4}{*}{$\begin{array}{l}\text { 駆 } \\
\text { 虫 } \\
\text { 犬 }\end{array}$} & No. 5 & 142 & 34 & 33 & 29 & 20 & 10.5 & 31 & 38 & 32 & 13 & 31 & 35 & 16 & 21 & 7 & 2 & 3 & 2 \\
\hline & No. 8 & 178 & 29 & 31 & 5 & 10 & 12.0 & 32 & 16 & 28 & 15 & 19 & 11 & 8 & 10 & 10 & 2 & 3 & 6 \\
\hline & No. 11 & 171 & 31 & 28 & 11 & 11 & 11.0 & 29 & 21 & 29 & 9 & 24 & 16 & 9 & 17 & 8 & 4 & 2 & 3 \\
\hline & 平均 & & 31 & 31 & 15 & 14 & & 31 & 25 & 30 & 12 & 25 & 21 & 11 & 16 & 8 & 3 & 3 & 4 \\
\hline
\end{tabular}

各分劃共著減しているが，特に肝の $\mathrm{P}_{\mathrm{I}}, \mathrm{P}_{\mathrm{II}}$ ，脾の PII，骨铕のPII に減少率が大きい，自然感染钧虫 犬の中 2 例は肝, 脾, 骨䯣の $\mathrm{P}_{\mathrm{I}}$, PII で健康犬より 少いが，駆虫犬上りやや多い傾向を示し， 1 例 (No. 10）は駆虫犬上り遙かに多く，踺康犬上りやや高い 值を示している，従つて平均値をとると，自然感染 鉤虫犬は肝，脾，骨随の PI， PII で駆虫犬より可成 多く，硉康犬よりやや少小值を示す。

以上を要約すれば訮，脾，骨随の PI，PII に於け 万鉄量は健争犬が最も多く，自然感染鉤虫犬は之よ りやや少く，駆虫犬は更に減少し，実験的鈎虫犬は 最も低値で著減している，十二指腸では各例の間に 殆ど差を認めない，又 P III，SIII は一般に比校的低: 値で一定の傾向を認めない.

\section{第4章 総括並びに考按}

以上の実験成績を総括すると次の如くである．即 ち一時に多数の鈳虫仔虫を経口感染せしめ肉眼的に あ著明な血便を見，出血多量であつたと考えられる 実験的鉤虫犬では，放射性鉄を経口投与後48㭙間の 観察に於て，経口投与された放射性鉄の吸収亟は極 めて高く，吸収された鉄はその大部分が血色䒺生成 に利用されて赤血球中に現わ机，胿，脾，骨賄に分
布する率は極めて低い．肉眼的㳊認められる程高度 の血便なく人鈎虫症に近い条件を備えると思われる 自然感染鉤虫犬の 2 例では，吸収は著明に隇退し， 吸収された鉄はその大部分が肝, 脾, 骨野に分布し, 血色萦生成には極く僅功が利用されているに過ぎな い. 自然感染鉤虫犬の中 1 例は健康犬よりやや高い 吸収率を示したが，駆虫犬に比较すると吸収率す低 く，各䑏器への分布状態も上記 2 例之同じ㑯向を示 している. 自然感染犬を駆虫した駆虫犬では吸收率 は可成り高く，吸収された鉄の大部分が血色羑生成 に利用され肝，脾，骨髄には少いが，之等の㑯向は 实験的鉤虫犬の方が著明である．澸器中の放射生錐

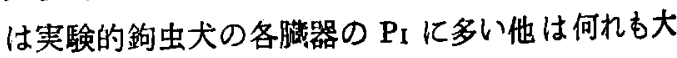

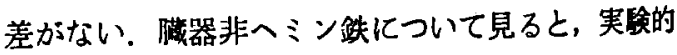
鉤虫犬では各䑏器各分䙵共著淈し, 自然感染钧蚛 では健水犬より少いが，駆虫犬よりやや多い佰向を 示しており，增娍の主体は $\mathrm{P}_{\mathrm{I}}, \mathrm{P}_{\mathrm{II}}$ である.

双て生体の鉄代謝は極めて複雑であるが， Moore等118）に従つて図式的に考元ると，鉄の吸收， 眝蔵，血色素生成及び呼吸醭委への利用，赫血球の 生理的又は病的な湖㙏，排泄及び之等を結ぶ血清柣 等が相互に関連し合つていて，鈎虫症の場合汇传更 に出血が加わる、緒言に於て述へた如く，出血は本 
貧血の重要な一因子として疑うへくるすい姏であり， 文溶血は著明に起つているとは考えられない，鉄の 体外排泄については Mc Cance \& Widdowson(17), Balfour(7), Hahn 100), Dubach84), Copp \& Greenberg81), 福島48), Stevens ${ }^{127)}$, Dubach85), Chappelle 7 ) 等の諸家により, 病的な溶血現象のある場

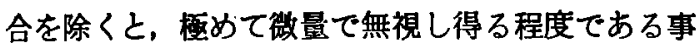
が確められている．従つて鉤虫症の鉄代謝を考える 場合，特に吸収，眝蔵，鉄の動員及び血色菜生成へ の利用等の面について相互関連の6とに検索すれほ， その大略をうかがうことが出来る。

先づ鉄は二価イオンとなつて，主として胃及び十 二指腸上部に於て吸収される. 291128996) 而して生体 の総鉄量は他の成分の様に無制限に吸収され，過剩 のものは排泄されると云う機構によつて調節される 6のではなく，専ら吸収を調節する事によつて鉄平 衝が保れる81) のであつて，その調節機構に関して は Hahn等103) の研究, 更化進んで Granik 92)93) の 所謂 Mucosal block 説がある. 又铁の吸収は鉄そ のあのの存在様式によつて異るのであつて, Habn等105）によれは์，人，犬共に二価の鉄塩の方 が三価のものより吸収が良いとし，Moore等119) は 人では二価の鉄塩の方が吸収が良く，犬では二価と 三価では大差がないとしている，更に鉄の吸収は混 在する消化管内容等によつても種々影䈏される事が 諸家(103)(20)114)108564) の研究に上つて明かである. 従 つて着者は経口投与には，アスコルビン酸を加えて 二価の形として与え，投与の前後は絶食せしめて消 化管内容の影䈉を避け，条件を一定にする様に努め た.

次に，吸収の良否を論ずる場合その判定方法が間 題となるのであつて，先蜸により述へられている主 な方法を細的ると次の様に分類出来る。

a）平衝試験：古く加ら态用されていたもので, 或一定期間内の投与総鉄量と総排泄量との差加ら吸 收量を求める方法であり，放射性鉄の利用により容 易となり，又正確にあなつた。

b）血清鉄の增加を標準とする方法：所調鉄吸 収曲線によるもので，ての曲線の高さを比較する事 によつて吸収の良否を判定する方法である．簡単で あり比校的よく利用されているか，吸収曲線の高さ は吸収のみてなく，血色素生成えの利用及び各践器 組織にとり入れられる程度にも影響される事を考虑 しなけれはチならない，著者の成䋶でも血整中の放射 生鉄の高さは吸収率と大体平行しているが，実験的
鉤虫犬 No. 4 は他に比し血墏中の放射性鉄が極めて 低值であるにも拘らず，吸収率は他と同様に甚だ高 く，之は血色素生成への利用が著明に六進している 為であり，上述の事をよく物語つている。

c）赤血球に現われる標識鉄量, 即与血色素生成 に利用された鉄量によつて判定するあのであり，正 常人，鉄欠乏性賓血の如く吸収量の全部が血色素生 成に利用されるものは良いが，利用が悪いか又は臟 器組織に鉄が強く捕捉される場合は不適当である。

d）全組織鉄を測定する方法：最む良い方法で あるが臨床上には応用出来ない，動物実験の際放射 性鉄を利用して，各劌器への分布を知るには誠に好 都合で，吸収完了後生体灌流で血液を除き次いで测 定すれば容易に量的関係を知り得る.

之等の方法は夫々長所, 欠点をむつているが，著 者は正確で吸収量を知ると共に各臟器への分布をも うかがう事が出来る d) の方法に準じて，鉄代謝に 最も関係深く，吸収された鉄の大部分を含む赤血球， 肝，脾，冎髄つ放射生鉄を測定する事に上り吸収の 良否を判定した。

著者の成樍を見るに，健隶犬では $5 \sim 6 \%$ の吸収 率を示し，Hahn101）が健隶犬で示した 0.08〜0.24 \%と云う值と比校すると相当な差があるが，之は投 与量に関係するのであつて，投与量を少くすると吸 収される絶対量は少くなるか，吸収率は大きくなる。 乙の点 Copp \& Greenberg81)が圂に生理的鉄最よ り更に少量を与えて，その約 $1 / 3$ が吸収された成縝 を示している事からあ明かである．実験的鈎虫犬で は吸収の著明なえ進が認められるが，Hahn101， Balfour75) 等が示す如く鉄は生体の需要仙忍して吸 収されるのであつて，肉眼的血便加ら，又吸収され た鉄の赤血球及び諸㶓器への分布，眝蔵鉄の著隇等 加ら見ても出血に上る著明な鉄欠之の為に吸収が䒕 進している事が判然としており，ての事については 更に後述する. 駆虫犬の吸収率仙実験的鈎虫犬には 及ぼないが，健隶犬より可成高く，膆器分布及び眝 蔵鉄の減少と共に，後述する如く貫血の恢復に伴う 鉄欠乏状態にある事を示している，自然感染钧虫犬 は人鈎虫症に最も近い条件を備えるむのと考えられ， この中 2 例飞著，明な吸収率つ低下を認め，鉤虫症に は相当著しい吸収障害がある事を示しており，今 1 例6健隶犬に比してやや吸収の亢進を示すとは云え， 血液像，眝蔵鉄量が示す如く殆ど同じ条件を備える と思われる自然感染犬を駆虫した駆虫犬に比して吸 収率が低い事を考えれば，やはり鈎虫寄生による吸 
収障害が存する事は明かである.

鈎虫症に消化障害がある事は大礎10）が強調し，

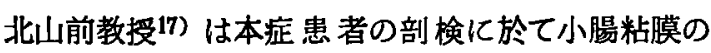
壊死其他著明な変化を認め，レ線検查に於ても小腸 の機能異常を指摘しておられる. 中尾34) す剖検上 小腸粘膜に著明な変化があると述べ,松本66) あ本症 患者の胃腸レ線検査で異常を認めている，等の事か らむ吸収障害の存在が推定出来る. 更に福島・千 田46)，教室中塚40）は本症患者えの還元鉄投与試験 で吸収障害を認め，岩城4)は経口投与した放射性鉄 の血漿中に於ける最高值の比較及び血色素生成への 利用率から吸収嘰構の破綻ありとしている. 然し乍 ら之等の実験方法は前述の如く吸収の良否判定に必 ずしも充分でなく，著者の実験によつて吸収障害の 存在をより正確に証明し得たと云える. 更にこの吸 収障害が鈎虫寄生による機械的障害つみによるもの とすれば，一時に大量感染し腸出血の著明な実験的 鈎虫犬の方に著明にあらわれる筈であるが，事実は 之に反し，又福島・千田46) が駆虫後は極めて早く 吸収能力が恢復する事を示している点等考えると， 機械的障害以外の原因，即ち鉤虫毒素の作用が推測 され興味深い。

次に吸収された鉄の眝蔵及び動員利用について検 索を進めよう，体内鉄の65～75\%は血色秦を主とす。 るへミン鉄に属し，呼吸，エネルギー代謝機構の醳 素的作用を営み，約20\%は眝蔵鉄として主として肝， 脾，骨髄に含まれる93)，又 Finch ${ }^{88)}$ によれば人と 犬の鉄代謝の様相はよく似ており，血色素生成と眝 蔵鉄之の関係は次の如くである，即ち吸収された鉄 は肝及び網内系に眝蔵され，眝蔵鉄は必要に応して 主として血色素生成の為に出動利用される. 正常状 態でも赤血球の崩壊，新生によつて，眝蔵鉄と血色 素鉄との間には循環があり，その鉄の動きは 1 日に 全血色素鉄の約 1 \%で，常に動的平衝の状態にある。 更に又 Dubach81)，Hampton107) の云うごとく，吸 収され或は少量静注されて新しく汗其他に取り入れ られた鉄は既存の眝蔵制に先んして利用される，從 つて吸収された鉄の赤血球，肝，脾，骨准道等への分 布状態を検索する事によつて鉄代謝を動的に把握す る事が出来る。

著者の実験成績に於て健捸犬と実験的鉤虫犬を比 較すると，吸収された鉄は後者では前者に於けるよ りあ遥汃に多くが血色素生成に利用され，その為に 肝，脾，骨䯣化は極好て低率で，前述の著しい吸収 の元進と共に, Hahn101)，Austoni \& Greenberg74)，
Copp \& Greenberg81)82)，中尾36）が犬，最，家鬼に ついて健康対照動物と鉄欠之状拍にした動物とを対 比した成績と極めてよく一致し，実験的鈎虫犬では 血色素生成への鉄の需要が極度に昂つて，吸収され た鉄の大部分が造血に利用されている事を示してい る. 而して奏験的鉤虫犬は鉤虫仔虫を一時に大最感 染させて作つたすので，肉眼的腸出血が強く，潜血 反応によつてやつと証明される人鉤虫症とは著明な 相違があり，之をあつて直ちに鈎虫症の鉄代謝を論 ずる事は出来ない，次に人鉤虫症に最す近い自然感 染鈎虫犬について見ると，之とは全く異つた成精を 示している. 即ち吸収された鉄の約半量は肝に，牫 りの大部分あ骨䯣，脾に認ぬられ，血色素生成への 利用は極めて少く，健康犬に比して著しい相違が見 られ，更に駆虫犬，実験的鈎虫犬と比較すると相違 は一層大きく，将に正反対の態度をとつている，自 然感染鉤虫犬の中 1 例 (No. 10) は他の 2 例とやや 異つた成績を示しているが，之も駆虫犬と比较する 之上記同様の傾向がある事は明かである. 駆虫犬は 駆虫前の血液像が自然感染鉤虫犬と略等しい自然感 染犬を駆虫したものであり，後述する眝蔵鉄も略同 じである，従つて駆虫犬は自然感染鉤虫犬から鉤虫 寄生が除かれたあので，との両者の間に全く正反対 の成績が得られた事は誠に興味深く，出血は両者共 に存するのであるから，出血以外の鈎虫寄生による 影響，即ち鈎虫毒素の影響が如何に大きいるのであ るかと云う事を端的に示しているすのと考えられる。 即ち鉤虫症に於ては，新しく吸収された鉄は貯蔵器 に捕捉され，動員され難い事を示している.

以上鈎虫症に於ては眝蔵器からの鉄の動員が障害 され，特異な態度をとる事が明かになつたが，眝蔵 鉄を更に分割定量した成績加ら眝蔵器内に於ける照 度を追求してみよう。処で盯蔵鉄はフェリチンへ モジデリン及び僅少の labile iron 加らなと考え られており，之等を分乵定量する試みは中島(99)， 米山・紺野72), Chase(0), Gabrio90), Hampton(06), Heilmeyer(10) 等によつて行われている. フェリチ ン鉄の眝蔵鉄としての重要性は比较的早くから強調 されている93) 処であるが，化学定量法によつて分 绪してみると，へモジデリンすフェリチンと同程度 に含まれ72)，負血，出血等の場合フェリチンと同じ く変動するから、ヘモジデリンす詝蔵鉄として重要 な役割を演じている事が知られた126)。吸収され或 は少哣静注された鉄が眝蔵鉄に取入れられる場合、

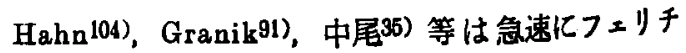


ンの分制に入るとし，島田24）は演血海㩧の恢復状 況功ェリチン分劃が一定量以上になるとへモジ デリンに移行すると述べ，Hampton106) は先づへモ ジデリンの形になり次いで代謝系に入つてフェリチ ンになると推定している. 又フェリチンとへモジデ リンといら゙れが早く動員されるかと云う点について， Shoden 126)，Hampton107）は瀉血実験で両者共同程 度に出動すると云い，Granik93)，中尾35)，須川(26)，

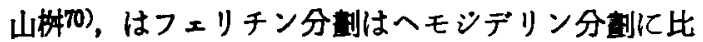
しより速に動員されると述へている，又山下69）は 演血時の脿器鉄分割の変化からフェリチン、へモジ デリンりあ更に代謝の早い単純な鉄蛋白結合体は 今迄考えられていたより案外多いと考えており，之 は Greenbeeg \& Wintrobe96) の labile iron pool なる概念之符合している様行思われる，以上の如く 眝蔵鉄については諸家の研究にも拘らず未だ不明な 点も多いが, フェリチン、へモジデリンがその主役 を演している事は明かである.

著者は米山・紺野72) 氏法に従つて臓器鉄を分劃 したのであるか，氏等によれば $\operatorname{Pr}$ は恐らくへモシ デリン鉄であり，PII は明かにフェリチン鉄である。 PIII の鉄は核蛋白並びに高分子化合物に結合した鉄， SIII は遊離の鉄と考えられ，共に量は少い，著者の 実験に於りる贜器分剽の放射性鉄を見るに，実験的

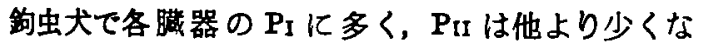
つているのは，一度䓨器に取入れられた鉄はPII 分 制の方が PI 上り動員され易い事を示しているもの と考元られる. 実医的鉤虫犬では吸収，利用が亢進 し，鉄の移動が著明な為にはつきりした変化が出た のので万う. 又自然感架鈎虫犬は吸収率が低いに 拘らず，PI，PII の放射性鉄は駆虫犬，健康犬上 大差なく，吸収された鉄の大部分が $\mathrm{P}_{\mathrm{I}}, \mathrm{PII}_{\mathrm{II}}$ に取入 れられ，そこから動員され難い事を示している. 次

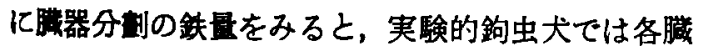
器各分制共著減し，之は Hoskins113)，Shoden 126), 山下(99)，教室水田78）等の演血実験の成績と一致し， 前述の諸成㧼と共に，腸出血が賓血の主因となつて いる事を示している，自然感染鉤虫犬は多少共腸出

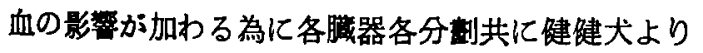
少いが，主として Pr，PIr で駆虫犬より多い，ての

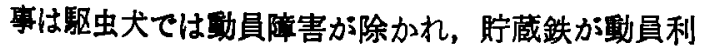
用された為，自然感染犬より少くなつたと考えられ， 教室中塚40)の示した出血の少い鈎虫犬に於ける眝 蔵鉄の増加之類似の傾向を示しており，前述の吸収 された鉄か眝蔵器に多く認められたの之同様に，眝
蔵器に入つた鉄は動貝され難い事を禾している。而 してての動員障害は駆虫によつて除かれるのであつ て，鉤虫毒素偟よつて惹起されるものと思われる。 尚腈器非へミン鉄及び吸収された放射性鉄は大部分 が PI，PII 亿認められ，貯蔵鉄の変動の主体はPI,

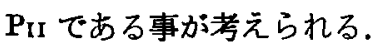

さきに福島・干田46)，岩城4（は鈎虫症に於ける 血清鉄の変動から，本症に於代る鉄動員の障害を推 定し，教室米谷52）は血清鉄の変動から，又更に鉤 虫症血清注射家鬼の眝蔵鉄の增加を半定晹的に証明 する事によつて，次いで教室中塚40）は鈎虫犬及び 鈎虫症血清注射家鬼の眝蔵鉄を分制定昌してその増 加を認めて，鉄の動員障害を確認しているが，著者 は上記の実験により貯蔵鉄の増加傾向のみならず， 吸収された鉄の特異な䑏器分布から，之を更に動的 に証明し得た。

以上を要約すると，自然感染鉤虫犬には鉄の吸収 及び動員の障害があり，之に出血による鉄欠之が加 わつて負血を来している，駆虫犬では鉤虫駆除によ つて吸収及び動員の障害が殆ど除かれ，盆血の恢復 が起つており，乙の貧血恢復に利用される鉄は吸収 される鉄及び眝蔵鉄である．而して貯蔵鉄の動員の みでは所盛な賓血の恢復による鉄の需要に間に合わ ない事, 又出血の影響によつて貯蔵鉄は健康犬に比 してやや減少している等の事から，主として貫血の 㤆復に伴う相対的鉄欠之状態となつて，吸収及び利 用が穴進しているものと考えられる. 実験的鉤虫犬 は鈎虫数が可成多いのに出血性貧血の様相を呈した のは，腸出血が極めて著明であり，感染後の期間が 短い事等から，出血の影響が鉤虫寄生による吸収及 び動員の障害より遥に強かつた為之解される。

\section{第 5 章 結 論}

鉤虫犬に放射性鉄を経口投与し，その吸収，䑏器 分布を追求し，同時江腀器鉄量も测定して，鉤虫症 に於ける鉄代謝の様相を検索した．鈎虫犬では鉄の 吸收率が低く，吸収された鉄はその大部分が肝，脾， 骨髄に認められ，赤血球に移行する率は極めて低く， 㖶器鉄量は健康犬より少く，駆虫犬より多かつた。 これらの事加ら鉤虫症には鉄の吸収及び動員の障害 があり，之等が出血と相俟つて貧血を来す事を動的 に確認した。 
稿を終るに当り終始御愁篤なる御指導と御梲閲を 睗つた恩師平木教授に深甚の謝意を表すると共に大 藤助教授の御校閲並飞木村博士の御援助を深㴬寸
る.

（文献は巻尾に一括記械する）

\title{
Studies on the Iron Metabolism in Hookworm Disease by means of Radioactve Iron ( $\mathrm{Fe}^{59}$ ) Administration
}

\section{Part 1. The Iron Metabolism in Dogs with Hookworm Disease}

\author{
By \\ Kaoru Uetsuka \\ Department of Internal Medicine Okayama University Medical School \\ (Director: Prof. Kiyoshi Hiraki)
}

Using dogs such as ones spontaneously infected with hookworms, ones dewormed of these hookworms, those experimentally infected with hookworms showing marked intestinal hemorrhage as well as normal dogs (the control), and orally administering them radioactive iron, $\mathrm{Fe}^{59}$, the author determined the radioactive iron in erythrocytes and plasm periodically. Then 48 hours later perfusion is given and fractionating the visceral iron by YoneyamaKonno's method, the iron contents and $\mathrm{Fe}^{59}$ are estimated.

As the results, it has been found that the iron-absorption rate is lowest in the dogs spontaneously infected with hookworms, followed in an ascending order of normal dogs and dewormed dogs, and highest in the dogs with experimental hookworm disease. As for the distribution of $\mathrm{Fe}^{59}$ absorbed, in the spontaneously infected dogs it is distributed mostly in the liver, spleen and bone marrow, demonstrating an extremely low portion of it taken into erythrocytes. In the dewormed dogs, on the contrary, the major portion of the absorbed $\mathrm{Fe}^{69}$ is taken up by erythrocytes and it is sparsely distributed in the liver, spleen and bone marrow, and this tendency is still more marked in the dogs with experimental hookworm disease, Furthermore, the iron contents of various organs in the dogs spontaneously infected with hookworms, though slightly less than in the normal, are greater than those found in the dewormed dogs, proving a marked decrease in the dogs with experimental hookworm disease. From these data it is assumed that there is a definite impediment to the absorption and mobilization of iron in hook worm disease and that such an impediment together with hemorrhage induce anemia. 